\title{
Trend and factors associated with Tuberculosis-Diabetes Mellitus comorbidity in a Northeastern Brazilian municipality
}

Tendência e fatores associados à comorbidade tuberculose diabetes mellitus em um município do Nordeste brasileiro

Tendencia y factores relacionados a la comorbilidad tuberculosis-diabetes mellitus en un municipio del Nordeste brasileño

Giana Gislanne da Silva de Sousa' ORCID: 0000-0003-1493-1706

Lívia Maia Pascoal' ORCID: 0000-0003-0876-3996

Ana Cristina Pereira de Jesus Costa" ORCID: 0000-0001-7757-8183

Floriacy Stabnow Santos" ORCID: 0000-0001-7840-7642

Leonardo Hunaldo dos Santos" ORCID: 0000-0003-2280-4643

Ricardo Alexandre Arcêncio"'" ORCID: 0000-0003-4792-8714

Marcelino Santos Neto' ORCID: 0000-0002-6105-1886

'Universidade Federal do Maranhão. São Luís, Maranhão, Brazil. "Universidade Federal do Maranhão. Imperatriz, Maranhão, Brazil.

"'Universidade de São Paulo. Ribeirão Preto, São Paulo, Brazil.

How to cite this article: Sousa GGS, Pascoal LM, Costa ACPJ, Santos FS, Santos LH, Arcêncio RA, et al. Trend and factors associated with Tuberculosis-Diabetes Mellitus comorbidity in a Northeastern Brazilian municipality. Rev Bras Enferm. 2021;74(3):e20201238. https://doi.org/10.1590/0034-7167-2020-1238

Corresponding author:

Giana Gislanne da Silva de Sousa

E-mail: giana.s@outlook.com

EDITOR IN CHIEF: Antonio José de Almeida Filho ASSOCIATE EDITOR: Hugo Fernandes

\section{ABSTRACT}

Objectives: to identify the trend and factors associated with Tuberculosis-Diabetes Mellitus comorbidity in Imperatriz, Maranhão. Methods: epidemiological temporal-series study conducted in a Northeastern Brazilian municipality. The population consisted of Tuberculosis cases with Diabetes Mellitus-associated aggravation notified in the Notifiable Diseases Information System (SINAN) between 2009 and 2018. We determined the prevalence and trend of comorbidity using Prais-Winsten regressions and to identify associated factors employed Poisson regression. Results: prevalence ranged from $3.23 \%$ in 2014 to $19.51 \%$ in 2018 , with a mean of $11.5 \%$ for the period, showing an increasing trend. Age groups 30 to 59 years and $\geq 60$ years, education $<8$ years, and clinical form of pulmonary Tuberculosis were risk factors for comorbidity. Conclusions: The increasing trend of comorbidity and its associated factors alert us to the need to improve customer service at all levels of health care. Descriptors: Tuberculosis; Diabetes Mellitus; Comorbidity; Prevalence; Epidemiological Monitoring.

\section{RESUMO}

Objetivos: identificar a tendência e os fatores associados à comorbidade tuberculose-diabetes mellitus em Imperatriz, Maranhão. Métodos: estudo epidemiológico de séries temporais, realizado em um município do Nordeste brasileiro. A população foi constituída pelos casos de tuberculose com agravo associado ao diabetes mellitus notificados no Sistema de Informação de Agravos de Notificação entre 2009 e 2018. Determinou-se a prevalência e tendência da comorbidade utilizando regressões de Prais Winsten. Para identificar os fatores associados, empregou-se regressão de Poisson. Resultados: a prevalência variou de 3,23\% em 2014 para $19,51 \%$ em 2018 , com média de $11,5 \%$ para o período, apresentando tendência crescente. As faixas etárias de 30 a 59 anos e $\geq 60$ anos, escolaridade $<8$ anos e forma clínica da tuberculose pulmonar foram fatores de risco para a comorbidade. Conclusões: a tendência crescente da comorbidade e seus fatores associados alertam para a necessidade de aperfeiçoamento do atendimento nos níveis de atenção à saúde.

Descritores: Tuberculose; Diabetes Mellitus; Comorbidade; Prevalência; Monitoramento Epidemiológico.

\section{RESUMEN}

Objetivos: identificar tendencia y factores relacionados a la comorbilidad tuberculosis diabetes mellitus en Imperatriz, Maranhão. Métodos: estudio epidemiológico de series temporales, realizado en municipio del Nordeste brasileño. La población constituida por casos de tuberculosis con agravio relacionado a diabetes mellitus notificados en Sistema de Información de Agravios de Notificación entre 2009 y 2018. Determinó la prevalencia y tendencia de la comorbilidad utilizando regresiones de Prais-Winsten. para identificar los factores relacionados empleó regresión de Poisson. Resultados: la prevalencia varió de 3,23\% en 2014 para 19,51\% en 2018, con mediana de 11,5\% para el período, presentando tendencia creciente. Rango etario de 30 a 59 años y $\geq 60$ años, escolaridad $<8$ años y forma clínica de la tuberculosis pulmonar fueron factores de riesgo para la comorbilidad. Conclusiones: la tendencia creciente de la comorbilidad y sus factores relacionados alertan para la necesidad de perfeccionamiento de la atención en los niveles de atención de salud.

Descriptores: Tuberculosis; Diabetes Mellitus; Comorbilidad; Prevalencia; Monitoreo Epidemiológico. 


\section{INTRODUCTION}

Tuberculosis (TB), the leading cause of death from infectious diseases worldwide, is caused by a single infectious agent called Mycobacterium Tuberculosis, transmitted through the upper airways and affecting mainly the lungs ${ }^{(1)}$. It also presents high rates of morbidity and mortality, especially in countries with more significant social inequalities ${ }^{(2-3)}$.

Global data pointed out that 10 million people get sick from TB worldwide, and 1.4 million died in $2019^{(1)}$. The most significant risk of becoming ill with TB occurs in the first two years after initial contact with the bacillus, but it can remain incubated for several decades ${ }^{(4)}$. It is estimated that a quarter of the world population is infected with the etiologic agent of $\mathrm{TB}^{(1)}$, and some factors associated with alterations in the immune system constitute risks for the development of active TB, highlighting cases of HIV infection, immunosuppressive diseases and/or treatments, extremes of age, children younger than two years old or the elderly, and Diabetes Mellitus (DM) ${ }^{(4)}$.

Specifically, DM, metabolic disease of multifactorial origin, responsible for elevating blood glucose, causes damages, dysfunction, and failure of organs such as eyes, kidneys, nerves, heart, and blood vessels $s^{(5-6)}$, generating changes in the immune system of the individual that make him more susceptible to infections such as $\mathrm{TB}^{(6-8)}$.

In this context, the TB-DM association has generated concerns regarding the control of the former since DM contributes to maintaining the infection cycle. Comorbid individuals are more likely to have TB-related complications and aggravations, such as multidrug resistance to treatment, decreased cure rates, and increased relapses ${ }^{(9-10)}$.

Studies point to the association of DM with high TB rates, considering that countries with a high prevalence of DM also have higher rates of TB incidence ${ }^{(7,11-12)}$. That happens because the chance of developing TB is 1.5 to 3 times greater in DM patients than in those without $\mathrm{it}^{\text {(13-14). }}$.

The high burden of DM in patients with active TB worldwide was accounted for, with a prevalence of $15.3 \%$ (15), and the high prevalence of the comorbidity occurred in underdeveloped or developing countries, such as Nigeria (9.4\%), Ethiopia (13.5\%), and India (25.35\%) (16-18). Furthermore, the general population's DM epidemic boosted the prevalence of $\mathrm{DM}$ among patients with active $\mathrm{TB}^{(15)}$.

In this perspective, Brazil stands out as the fifth country in the world with the most significant number of individuals with $\mathrm{DM}^{(19)}$ and is on the World Health Organization (WHO) list among the 30 countries with a high burden of $\mathrm{TB}^{(1)}$. The percentage of people in the country with TB who had DM increased from $5.5 \%$ to $7.7 \%$ from 2009 to $2017^{(20)}$. Given this epidemiological panorama, we realize the need for actions directed to the control of comorbidity, considering that the social and economic impacts and health problems are greater when these diseases are associated ${ }^{(21)}$.

DM is among the five leading risk factors for TB development and mortality, so that monitoring its prevalence constitutes a strategy for reducing the burden of TB worldwide, justifying the use of data on the prevalence of DM in patients with TB for planning care focused on the comorbidity ${ }^{(1)}$. Information on the sociodemographic and clinical-epidemiological characteristics of TB-DM comorbidity cases and their trends are relevant since it constitutes tools that help in the appropriate clinical management of both diseases, which is still poorly understood among healthcare professionals ${ }^{(6,8)}$.

An integrative literature review ${ }^{(22)}$ demonstrated that the high prevalence of DM cooperates with the increase in TB cases, influencing its severity and causing more severe symptoms of the disease. Comorbid patients mainly present advanced age, female gender, and low family income. Out of the sixteen eligible studies, only six were conducted in Brazil, and none of them addressed the endemic scenario of the Brazilian Northeast, a region whose socioeconomic and operational indicators of TB demand special attention by health systems and services ${ }^{(23)}$.

In addition to unfavorable socioeconomic conditions that are strongly related to TB, factors such as urbanization, sedentary lifestyles, overweight, population growth, and aging impact the higher prevalence of chronic diseases, such as DM. This convergence of factors favors the development of TB, making this disease a priority for public health worldwide ${ }^{(24-25)}$, revealing the need to explore and advance knowledge of the epidemiological reality of cases of TB-DM comorbidity.

\section{OBJECTIVES}

To identify the trend and factors associated with TuberculosisDiabetes Mellitus comorbidity in Imperatriz, state of Maranhão.

\section{METHODS}

\section{Ethical aspects}

This investigation, attending to the ethical precepts of research, was approved by the Research Ethics Committee (REC) of the Federal University of Maranhão (UFMA).

\section{Design, period, and place of study}

It is an epidemiological temporal-series study ${ }^{(26)}$ guided by the STROBE tool and conducted from 2009 to 2018 in Imperatriz, Maranhão, Northeast Region of Brazil. Located in the southwest of Maranhão, $626 \mathrm{~km}$ from the capital São Luís, the municipality has a territorial area of $1,368,988 \mathrm{~km}^{2}$ and an estimated population of 258,016 inhabitants, with more than $94 \%$ of them residing in urban areas ${ }^{(27)}$. It is considered the second-largest population center and commercial and services hub of the state ${ }^{(28)}$. For the confrontation of TB in Brazil, since 2017, scenarios were defined to be worked on in the coming years related to the goal of reducing the incidence of the disease in Brazil. The municipality is inserted in scenario 2.3, characterized by socioeconomic and operational indicators less favorable ${ }^{(23,29)}$, presenting, during the period of this study, an average TB incidence of 25.8/100,000 inhabitants ${ }^{(30)}$.

\section{Population or sample of study: criteria of inclusion and exclusion}

The study included all TB cases with associated aggravation of DM recorded in the Notifiable Diseases Information System (SINAN) in the period between January 2009 and December 2018 in the municipality of Imperatriz. It excluded cases with misdiagnosis and those not marked with the variable "TB-DM comorbidity". 


\section{Study protocol}

Data collection occurred in November 2019 by extracting variables via SINAN from the Health Surveillance Service (SVS) of the Regional Health Management Unit of Imperatriz (UGRSI). For characterization of cases at the individual level, variables related to individual notification data (age, gender, race/color, and education), residence (zone), and additional case data (clinical form, sputum smear microscopy, radiography, and sputum culture) were obtained from the TB compulsory notification forms.

\section{Data analysis and statistics}

Initially, a descriptive analysis of the sociodemographic and clinical, epidemiological variables was performed by determining absolute and relative frequencies. The prevalence in percentage values of the comorbidity TB-DM was defined each year by dividing the number of patients with the comorbidity by the number of existing TB cases. The mean prevalence for the period was also determined, considering the sum of the prevalence for the period, divided by 10 , referring to the study period (ten years).

The study used Prais-Winsten regressions to analyze the prevalence trend between 2009 and 2018, considering autocorrelation in temporal-series ${ }^{(31)}$. The calculation proposed by Antunes ${ }^{(32)}$ was employed to calculate the annual growth rate (AGR) and respective confidence intervals. Based on these parameters, the annual growth rate was classified as increasing, stable, or decreasing, where a non-significant $p$-value resulted in a stable trend (accepting the null hypothesis that the prevalence rate did not change over the years), and significant $p$ values resulted in the classification of an increasing trend (positive AGR) and a decreasing trend (negative AGR).

This study adopted Poisson regression models with robust adjustment of variance ${ }^{(33-34)}$ to identify factors associated with TB-DM comorbidity and included the sociodemographic and clinical-epidemiological variables that presented a $\mathrm{p}$-value $\leq$ 0.20 in the adjusted model. Prevalence ratios (PR) and respective $95 \%$ confidence intervals $(95 \% \mathrm{Cl})$ were estimated directly by the model's regression coefficients. At that time, the ignored data were excluded. The study tabulated data in Microsoft Office Excel $^{\circ} 2019$ spreadsheets and performed tests in IBM Statistical Package for Social Sciences (SPSS) software, version 24.0, at a $5 \%$ significance level.

\section{RESULTS}

Between 2009 and 2018, 721 TB cases were reported, of which 81 were associated with DM. In fifteen TB cases, the TB-DM comorbidity variable was not properly filled out.

The prevalence ranged from $3.23 \%$ in 2014 to $19.51 \%$ in 2018 , with an average of $11.29 \%$ throughout the evaluated period. Increased comorbidity prevalence over the decade was observed as the percentage went from $7.59 \%$ in 2009 to $19.51 \%$ in 2018 (Figure 1). Also, the prevalence of MD-TB showed a growing trend over the years, with an annual growth rate of $21.6 \%(p=$ 0.048) (Table 1).

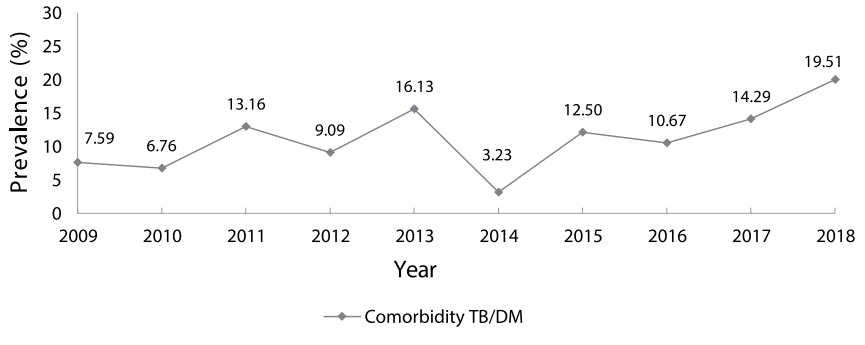

Note: TB - Tuberculosis; DM - Diabetes Mellitus.

Figure 1 - Prevalence of Tuberculosis-Diabetes Mellitus comorbidity in the period from 2009 to 2018, Imperatriz, Maranhão, Brazil

Table 1 - Trend in the prevalence of the comorbidity tuberculosis-Diabetes Mellitus between 2009 and 2018, Imperatriz, Maranhão, Brazil

\begin{tabular}{lcccccc}
\hline Period & $\begin{array}{c}\text { Annual } \\
\text { Growth } \\
\text { Rate (\%) }\end{array}$ & $\begin{array}{c}\text { Cl 95\% } \\
\text { Inferior Superior }\end{array}$ & $\mathbf{R}^{\mathbf{2}}$ & $\begin{array}{c}\boldsymbol{p} \\
\text { value* }\end{array}$ & Situation \\
\hline $2009-2018$ & 21.6 & -27.3 & 103.3 & 0,0449 & 0,048 & Increase \\
\hline $\begin{array}{l}\text { Note: *Prais-Winsten regression }(p<0.05) ; 95 \% \mathrm{Cl}-95 \% \text { confidence interval; } R^{2} \text { - coefficient } \\
\text { of determination. }\end{array}$
\end{tabular}

As for the sociodemographic characterization of the cases with comorbidity, most individuals were male $(n=50 ; 61.73 \%)$, aged $\geq 60$ years $(n=37 ; 45.68 \%)$, of mixed race/color $(n=47 ; 58.02 \%)$, with an education level $\leq 8$ years $(n=53 ; 65.43 \%)$ and living in urban areas $(n=80 ; 98.77 \%)$. There was a predominance of the pulmonary clinical form of TB $(n=79 ; 97.54 \%)$, with pulmonary alterations on the chest $X$-ray $(n=72 ; 88.90 \%)$ and positive sputum smear microscopy $(n=46 ; 56.80 \%)$. Ignored education $(n=$ $16 ; 19.76 \%)$ and sputum culture not performed $(n=72 ; 88.89 \%)$ were also response variables (Table 2).

Table 2 - Description of sociodemographic and clinical-epidemiological characteristics of cases with comorbidity tuberculosis-diabetes mellitus, Imperatriz, Maranhão, Brazil, 2009 to 2018

\begin{tabular}{lcc}
\hline Variables & \multicolumn{2}{c}{ Comorbidity TB-DM } \\
& $\begin{array}{c}\text { Yes } \\
\mathbf{n}(\%)\end{array}$ & $\begin{array}{c}\text { No } \\
\mathbf{n}(\%)\end{array}$ \\
\hline Gender & & \\
Female & $31(38.27)$ & $236(37.76)$ \\
Male & $50(61.73)$ & $389(62.24)$ \\
Age (Years) & & \\
$0-19$ & $1(1.23)$ & $59(9.44)$ \\
$20-39$ & $13(16.05)$ & $271(43.36)$ \\
$40-59$ & $30(37.04)$ & $180(28.80)$ \\
$\geq 60$ & $37(45.68)$ & $115(18.40)$ \\
Race/color & & \\
Asian & $2(2.47)$ & $12(1.92)$ \\
Black & $12(14.81)$ & $79(12.64)$ \\
White & $20(24.70)$ & $142(22.72)$ \\
Brown & $47(58.02)$ & $383(61.28)$ \\
Native & $0(0.00)$ & $4(0.64)$ \\
Ignored & $0(0.00)$ & $5(0.80)$ \\
Education (years) & & \\
$>8$ & $11(13.58)$ & $197(31.52)$ \\
$\leq 8$ & $53(65.43)$ & $313(50.08)$ \\
lgnored & $16(19.76)$ & $99(15.84)$ \\
Not Applied & $1(1.23)$ & $16(2.56)$ \\
Zone of residence & & \\
Rural area & $0(0.00)$ & $9(1.44)$ \\
Urban area & $80(98.77)$ & $606(96.96)$ \\
Ignored & $1(1.23)$ & $10(1.60)$ \\
\hline & & To be continued \\
& &
\end{tabular}


Table 2 (concluded)

\begin{tabular}{lcc}
\hline & \multicolumn{2}{c}{ Comorbidity TB-DM } \\
Variables & $\begin{array}{c}\text { Yes } \\
\mathbf{n}(\%)\end{array}$ & $\mathbf{n}(\%)$ \\
\hline Clinical form & & \\
Pulmonary + extrapulmonary & $1(1.23)$ & $11(1.76)$ \\
Extrapulmonary & $1(1.23)$ & $68(10.88)$ \\
Pulmonary & $79(97.54)$ & $546(87.36)$ \\
Radiography & & \\
Normal & $1(1.23)$ & $20(3.20)$ \\
Suspicious & $72(88.90)$ & $505(80.80)$ \\
Other pathology & $1(1.23)$ & $10(1.60)$ \\
Not performed & $7(8.64)$ & $86(13.76)$ \\
lgnored & $0(0.00)$ & $4(0.64)$ \\
Sputum Smear Microscopic & & \\
Negative & $24(29.63)$ & $189(30.24)$ \\
Positive & $46(56.80)$ & $271(43.36)$ \\
Not performed & $10(12.34)$ & $155(24.80)$ \\
Not Applied & $1(1.23)$ & $10(1.60)$ \\
Sputum Culture & & \\
Positive & $2(2.47)$ & $18(2.88)$ \\
Negative & $7(8.64)$ & $50(8.00)$ \\
In Progress & $0(0.00)$ & $2(0.32)$ \\
Not performed & $72(88.89)$ & $555(88.80)$ \\
Total & 81.00 & 625.00 \\
\hline Note: TB- tuberculosis;DM-Diabetes Mellitus. & &
\end{tabular}

Table 3 - Raw and adjusted Poisson regression analysis of sociodemographic and clinical-epidemiological characteristics of the cases of comorbidity Tuberculosis-Diabetes Mellitus, Imperatriz, Maranhão, Brazil, 2009 to 2018

\begin{tabular}{|c|c|c|c|c|}
\hline \multirow[b]{2}{*}{ Variables } & \multicolumn{4}{|c|}{ Comorbidity TB-DM } \\
\hline & $\begin{array}{l}\text { Raw RP } \\
\text { (IC 95\%) }\end{array}$ & $p$ value* & $\begin{array}{l}\text { Adjusted RP } \\
\text { (IC 95\%) }\end{array}$ & $p$ value* \\
\hline \multicolumn{5}{|l|}{ Gender } \\
\hline Female & 1 & - & - & - \\
\hline Male & $1.00(0.96-1.03)$ & 0.93 & - & - \\
\hline \multicolumn{5}{|l|}{ Age (years) } \\
\hline $0-19$ & 1 & - & 1 & - \\
\hline $20-39$ & $1.00(0.97-1.06)$ & 0.26 & $1.04(0.99-1.08)$ & 0.09 \\
\hline $40-59$ & $1.27(1.20-1.34)$ & $<0.001^{* *}$ & $1.50(1.38-1.72)$ & $<0.001^{* *}$ \\
\hline$\geq 60$ & 1.51 (1.39-1.78) & $<0.001^{* *}$ & $2.00(1.89-2.21)$ & $<0.001^{* *}$ \\
\hline \multicolumn{5}{|l|}{ Race/color } \\
\hline Native & 1 & - & 1 & - \\
\hline Asian & $1.15(0.96-1.39)$ & 0.23 & $1.14(0.94-1.39)$ & 0.19 \\
\hline Black & 1.01 (0.93-1.05) & 0.21 & $1.09(0.99-1.21)$ & 0.19 \\
\hline White & $1.14(0.97-1.19)$ & 0.25 & $1.08(0.97-1.16)$ & 0.17 \\
\hline Brown & $1.10(1.03-1.15)$ & $0.04^{* *}$ & $1.06(0.96-1.14)$ & 0.08 \\
\hline \multicolumn{5}{|l|}{ Education (years) } \\
\hline$>8$ & 1 & - & 1 & - \\
\hline$\leq 8$ & $1.60(1.55-1.655)$ & $<0.001^{* *}$ & $2.05(1.93-2.19)$ & $0.02^{* *}$ \\
\hline \multicolumn{5}{|l|}{ Clinical form } \\
\hline $\begin{array}{l}\text { Pulmonary + } \\
\text { extrapulmonary }\end{array}$ & 1 & - & - & - \\
\hline Extrapulmonary & $0.93(0.80-1.10)$ & 0.40 & - & - \\
\hline Pulmonary & $1.22(1.11-1.37)$ & 0.09 & $1.49(1.36-1.69)$ & $0.02^{* *}$ \\
\hline \multicolumn{5}{|l|}{ Radiography } \\
\hline Normal & 1 & - & - & - \\
\hline Suspicious & 1.08 (0.98-1.19) & 0.28 & - & - \\
\hline Other pathology & $1.04(0.86-1.27)$ & 0.66 & - & - \\
\hline Not performed & $1.03(0.92-1.14)$ & 0.62 & - & - \\
\hline \multicolumn{5}{|l|}{$\begin{array}{l}\text { Sputum Smear } \\
\text { Microscopic }\end{array}$} \\
\hline Not performed & 1 & - & 1 & - \\
\hline Negative & $1.05(0.99-1.11)$ & 0.27 & $1.03(0.96-1.10)$ & 0.39 \\
\hline Positive & $1.09(1.03-1.15)$ & $0.02^{* *}$ & $1.08(1.01-1.15)$ & 0.18 \\
\hline \multicolumn{5}{|l|}{ Sputum Culture } \\
\hline Positive & 1 & - & - & - \\
\hline Negative & $1.02(0.94-1.11)$ & 0.60 & - & - \\
\hline Not performed & $1.02(0.99-1.04)$ & 0.24 & - & - \\
\hline
\end{tabular}

Note: *Wald's chi-square; **Statistical significance - Raw PR $p \leq 0.20 ;$ Adjusted PR $p<0.05 ; T B$ - Tuberculosis; DM - Diabetes Mellitus; $P R$ - prevalence ratio; $95 \%$ CI - 95\% confidence interval.
In the raw analysis, the variables that showed significant associations for TB-DM comorbidity were age, age groups 40 to 59 years and $\geq 60$ years, education $<8$ years, race/color brown, and positive sputum smear microscopy. In the adjusted analysis, age groups 30 to 59 years $(P R=1.50 ; 95 \% \mathrm{Cl} 1.381 .72)$ and $\geq 60$ years $(P R=2.00 ; 95 \% \mathrm{Cl} 1.89-2.21)$, education $<8$ years $(P R=2.05 ; 95 \%$ $\mathrm{Cl} 1.932 .19)$, and clinical form of pulmonary TB (PR $=1.49 ; 95 \%$ $\mathrm{Cl}$ 1.36-1.69) were the variables that increased the odds for the occurrence of TB-DM comorbidity (Table 3 ).

\section{DISCUSSION}

The objective was to identify the trend and factors associated with TB-DM comorbidity in Imperatriz, Maranhão. Thus, it was observed that the prevalence of TB-DM in the municipality showed a significantly increasing trend between 2009 and 2018. When investigating the isolated trend of DM prevalence, a study conducted in Brazil from 1980 to 2014 pointed to a progressive DM growth over time ${ }^{(35)}$. In Taiwan, from 2000 to 2010 , DM prevalence among TB patients progressively increased from $21.6 \%$ to $31.5 \%$, with a mean rate of $27.9 \%{ }^{(36)}$, demonstrating that in countries where the DM prevalence is progressing, TB has remained a health problem ${ }^{(24)}$.

Corroborating such findings, studies conducted in the United States ${ }^{(37)}$ and in Spain ${ }^{(38)}$ have also shown an increase in comorbidity prevalence over time. Although the number of TB cases has been decreasing in countries like the United States, the prevalence of DM as comorbidity reported among adults with TB has steadily grown due to the high DM prevalence ${ }^{(37)}$.

The prevalence of DM has increased more rapidly in low- and middle-income countries, which has impacted infectious disease rates since the immune dysfunction caused by DM is related to high susceptibility to infections, including TB infection ${ }^{(39)}$. This result can be explained because dysglycemia, defined as abnormal blood glucose levels, impairs the immune response of individuals, increasing the likelihood of diabetic and prediabetic patients having latent TB when compared to those without DM, and, also, facilitates primary TB infection or reactivation of latent $\mathrm{TB}^{(39)}$.

The mean prevalence of TB-DM comorbidity detected during the evaluated period was $11.29 \%$, therefore higher than other studies conducted in Brazil, which reported prevalence rates of $6.0 \%{ }^{(40)}$ and $7.2 \%{ }^{(24)}$. A systematic review with a meta-analysis conducted to estimate the prevalence of diabetes among TB patients at the global, regional, and national levels demonstrated that the prevalence of the comorbidity was $15.3 \%$ at the global level, and Brazil presented a mean of $7.2 \%$, ranging from $3.3 \%$ to $33.1 \%$ in the studies conducted nationwide ${ }^{(15)}$. This investigation revealed results higher than the national average but was within the variation of rates found in the country.

When considering the global prevalence, another study showed similar results, with an approximate average of $16 \%$, ranging from $1.9 \%$ to $45 \%$ until 2016 , reported in several countries ${ }^{(41)}$. Studies conducted in Mexico (33\%)(11) and Paraguay $(6.2 \%)^{(42)}$ are examples of the variability of prevalence in specific scenarios, which can be caused by economic, demographic, geographic, and epidemiological diversity inherent in distinct populations, resulting in the heterogeneity of the distribution of comorbidity around the world $^{(42-43)}$. 
These significant differences in comorbidity prevalence rates may be explained by the DM prevalence rate variation in the respective countries' general population ${ }^{(15,41)}$ and how data are collected since different DM screening methods are used. In some studies, screening was performed using primary data collected by monitoring capillary blood glucose and glycated hemoglobin test $(\mathrm{HbA} 1 \mathrm{c})$ during the patient's hospital stay or performing screening tests ${ }^{(8,15)}$. Other studies used secondary data obtained through the national information systems, such as investigations carried out in Brazil using SINAN ${ }^{(21,40)}$.

The prevalence estimated in this study was based on secondary data and therefore may be lower than that reported in studies that progressively evaluated comorbidity and used methods to diagnose DM in all TB patients ${ }^{(8,42)}$. Although this study did not perform such an investigation, there is the possibility that, until TB notification, patients had not undergone testing for DM. This fact may have directly influenced the comorbidity's prevalence in 2014 (3.23\%), which showed an accentuated decline, followed by a significant increase in 2015 (12.50\%). In this regard, the literature points out that the prevalence of comorbidity is higher when screening tests for DM are performed at the time of TB diagnosis ${ }^{(36,43)}$.

A study that determined DM prevalence among newly diagnosed TB patients indicated that when screening about 31 TB patients with no history of DM, it was found one case of newly diagnosed $\mathrm{DM}^{(36)}$. While investigating pulmonary TB prevalence from four endemic countries, researchers identified that two-thirds of patients with DM already had a previous DM diagnosis; the remaining third was determined at the time of TB diagnosis ${ }^{(43)}$.

Research that related data from SINAN-TB and the System of Clinical Management of High Blood Pressure and Diabetes Mellitus at Primary Care (Brazilian SISHIPERDIA) showed discrepancies in the records since 3,181 cases of the comorbidity did not have the field of disease associated with DM checked in the SINAN$T B$, showing cases of the comorbidity that were not reported ${ }^{(21)}$, a fact that may also have had repercussions on the variation of prevalence in the scenario under investigation.

In this perspective, there is an emerging need for screening by the Primary Health Care service (PHC) in patients with TB to identify cases of previously undiagnosed DM, since it is essential for better surveillance and control of comorbidity, promoting the implementation of actions aimed at the integrated management of diseases ${ }^{(8,41)}$.

As regards the sociodemographic and clinical-epidemiological variables of TB-DM cases, the data obtained in the present investigation corroborate other studies, in which the population was also composed, in the majority, of males, of advanced age, of brown race/color, and with a low level of education ${ }^{(6,8,40)}$. Moreover, other studies also showed similarities in clinical aspects: new cases, with the pulmonary clinical form of $\mathrm{TB}^{(6)}$, presenting pulmonary alterations on chest X-rays and positive sputum smear microscopy ${ }^{(9,38)}$.

Regarding comorbidity's association with sociodemographic factors, it was observed in this research that the risk of presenting the comorbidity was enhanced with progressing age, being twice as high in people aged 60 years or more. A study conducted in Brazil showed that the risk was about 12 times higher in those aged 40 to 59 years and 17.5 times higher in those aged over 60 years ${ }^{(24)}$.
In other settings around the world, advanced age ( $\geq 60$ years) was also a factor associated with the development of TD-DM ${ }^{(7,9,12)}$.

It is essential to highlight that, although TB is more common in young adults, the elderly population continues to be the most affected by type $2 \mathrm{DM}$, and the occurrence of TB in the age group over 40 years coincides with the onset of DM, which makes middle age and advanced age risk factors for the occurrence of this comorbidity ${ }^{(7,14)}$. This relationship can be attributed to physiological changes that affect the functions of the immune and metabolic systems with advancing age, making the individual's body susceptible to both infections and chronic non-infectious diseases ${ }^{(41)}$.

Besides, alterations in lung function and mucociliary clearance in older adults, associated with the immunological vulnerability caused by DM, favor the development of $\mathrm{TB}^{(14)}$. DM and the physiological aging process synergistically reduce interferon-gamma levels, impairing cell-mediated immunity that contributes to the activation of long-standing latent $\mathrm{TB}^{(37)}$.

In this research, individuals with up to eight years of schooling were twice as likely to present comorbidity. As evidenced in the literature $\mathrm{e}^{(14,21,24)}$, the findings revealed that the comorbidity was related to unfavorable socioeconomic conditions, affecting those in social vulnerability ${ }^{(7)}$.

The low level of education is associated with a higher prevalence of $\mathrm{TB}^{(44)}$ and $\mathrm{DM}^{(45)}$. That occurs due to the limited access to information and the lack of understanding of the diseases, leading to DM's occurrence and greater transmissibility of TB. Furthermore, education is a socioeconomic indicator; therefore, the risk of becoming ill may also relate to the difficulty of access to health services and the ineffectiveness of preventive measures ${ }^{(44,46)}$.

Furthermore, the abandonment of therapy, drug resistance, and, consequently, treatment failure may be related to few years of education since insufficient knowledge of the diseases and their health status contributes to low adherence to therapeutic measures ${ }^{(46)}$. Moreover, when there is a lower level of education, there must be a better dialogue between healthcare professionals and patients so that there is an understanding of the care directed to the comorbidity's clinical management ${ }^{(14)}$.

This investigation also found an association between TB-DM comorbidity and the clinical form of the disease, in which residents were approximately 1.5 times more likely to present pulmonary $\mathrm{TB}$, a result similar to that of other studies ${ }^{(6,14)}$. Such findings are the result of an immunological vulnerability in DM cases, which causes failures in pulmonary defense mechanisms, generated by the inability of alveolar macrophages to eliminate mycobacterial infection and by the decreased mucociliary function of the lungs, especially in older individuals, favoring the manifestation of pulmonary TB, which directly influences the higher transmission of the disease in comorbid patients ${ }^{(4)}$.

\section{Study limitations}

As limitations of this study, we highlight that the SINAN form does not require completing the TB-related disease field, which contributes to the comorbidity's underreporting. Also, the SINANTB forms present limitations related to the low completeness of fields in the essential variables, such as education and race/ color, and those related to treatment monitoring, such as sputum 
smear microscopy. Also, fields related to laboratory tests, such as sputum culture, are not updated ${ }^{(47)}$.

There are deficiencies in training professionals to fill out the reports, considering that some consider the notification forms' completion as a merely bureaucratic task of the surveillance. Therefore, it is suggested that, in addition to implementing continuing education activities with the professionals responsible for the notification, studies should be conducted to identify the gaps in knowledge regarding health surveillance records in order to guide the actions aimed at improving the quality of TB cases records and concomitant morbidities ${ }^{(47)}$. One should also consider the limitation of the cross-sectional model, which does not allow the establishment of cause and effect relationships.

\section{Contributions to Nursing, Health and Public Policy}

Researches involving health surveillance are of high relevance to nursing because, during their academic training, nurses are prepared to work in epidemiological research, being on the front line of healthcare and in direct contact with users, families, the community, and the multidisciplinary team, actively participating in the health-disease process of the population and consequently acting in the conduction of public health actions ${ }^{(48)}$.

Besides, epidemiological studies are essential since nurses are professionals responsible for TB control actions, carrying out care, prevention, and health promotion work. Such data can serve as tools that help in the management and planning of health strategies directed to the control of this disease ${ }^{(49)}$.

\section{CONCLUSIONS}

Based on the results obtained, it was found that the prevalence of TB-DM comorbidity showed an increasing trend over the period evaluated. Sociodemographic and clinical epidemiological factors, such as age in the 30 to 59 and over 60-year groups, low education level, and pulmonary clinical form of TB, were associated with comorbidity in the scenario investigated.

This trend and its associated factors alert us to the need to improve assistance at all healthcare levels. The results also generate subsidies for strategic planning of management and health services, contributing to the control of the double burden of diseases, given the implementation of effective measures for integrated management, reduction of differences in exposure and vulnerability to diseases, as well as the introduction of measures that benefit intersectoral actions and social protection.

\section{FUNDING}

Research funded by the Foundation for Research and Scientific and Technological Development of Maranhão (FAPEMA) and by the Coordination for the Improvement of Higher Education Personnel - Brazil (CAPES) - Finance Code 001.

\section{ACKNOWLEDGMENT}

We thank the Health Surveillance Service (HSS) of the Regional Health Management Unit of Imperatriz (UGRSI) for providing the data.

\section{REFERENCES}

1. World Health Organization (WHO). Global tuberculosis report 2020 [Internet]. Geneva:WHO; 2020 [cited 2020 Nov 6]. Available from: https://apps.who.int/iris/bitstream/handle/10665/336069/9789240013131-eng.pdf?ua=1

2. Harling G, Lima Neto AS, Sousa GS, Machado MM, Castro MC. Determinants of tuberculosis transmission and treatment abandonment in Fortaleza, Brazil. BMC Public Health. 2017;17(1):508. https://doi.org/10.1186/s12889-017-4435-0

3. San Pedro AS, Gibson G, Santos JP, Toledo LM, Sabroza PC, Oliveira RM. Tuberculosis as a marker of inequities in the context of socio-spatial transformation. Rev Saúde Pública. 2017;51(9). https://doi.org/10.1590/s1518-8787.2017051006533

4. Busatto C, Reis AJ, Valim AR, Nunes LS, Carneiro M, Possuelo LG. Tuberculose ativa versus tuberculose latente: uma revisão de literatura. J Infec Control [Internet]. 2015 [cited 2020 Nov 6];4(3):60-4. Available from: http://www.jic-abih.com.br/index.php/jic/article/view/116

5. Kumar NP, Sridhar R, Nair D, Banurekha VV, Nutman TB, Babu S. Type 2 diabetes mellitus is associated with altered CD8+ T and natural killer cell function in pulmonary tuberculosis. Immunology. 2015;144(4):677-86. https://doi.org/10.1111/imm.12421

6. Lopes BK, Antunes IA, Nepomuceno GK, Cardoso EC, Santos Castro J, Silva LM, et al. Tuberculosis-diabetes comorbidity at the state reference center in sanitary pneumology in Manaus-AM. Braz J Health Rev. 2020;3(4):10807-25. https://doi.org/10.34119/bjhrv3n4-287

7. Leal SB, Araújo GS, Nery JS, Santos CA, Oliveira MG, Barreto ML, et al. Clinical and epidemiological aspects of cases of tuberculosis associated with diabetes in Salvador, Bahia, Brazil. Rev Soc Bras Med Trop. 2017;50(3):408-12. https://doi.org/10.1590/0037-8682-0409-2016

8. Nascimento CV, Soares SM. Co-management of tuberculosis and diabetes: an integrative review. Rev Panam Salud Publica. $2019 ; 43:$ e21. https://doi.org/10.26633/rpsp.2019.21

9. Gil-Santana L, Almeida Jr JL, Oliveira CA, Hickson LS, Daltro C, Castro S, et al. Diabetes Is Associated with Worse Clinical Presentation in Tuberculosis Patients from Brazil: A Retrospective Cohort Study. PLoS ONE. 2016;11(1):e0146876. https://doi.org/10.1371/journal.pone.0146876

10. Leal ML, Maciel EL, Cade NV. Factors associated with tuberculosis in a population of diabetics: A case-control study. Ciênc Saúde Coletiva. 2019;24(9):3247-56. https://doi.org/10.1590/1413-81232018249.30392017

11. Blanco-Guillot F, Castañeda-Cediel ML, Cruz-Hervert P, Ferreyra-Reyes L, Delgado-Sánchez G, Ferreira-Guerrero E, et al. Genotyping and spatial analysis of pulmonary tuberculosis and diabetes cases in the state of Veracruz, Mexico. PloS One. 2018;13(3):1-20. https://doi. org/10.1371/journal.pone.0193911 
12. Workneh MH, Bjune GA, Yimer SA. Prevalence and associated factors of diabetes mellitus among tuberculosis patients in South-Eastern Amhara Region, Ethiopia: a cross sectional study. PloS One. 2016;11(1):1-15. https://doi.org/10.1371/journal.pone.0147621

13. Hayashi S, Chandramohan D. Risk of active tuberculosis among people with diabetes mellitus: systematic review and meta-analysis. Trop Med Int Health. 2018;23(10):1058-70. https://doi.org/10.1111/tmi.13133

14. Lacerda SN, Silva TC, Araújo PD, Pinto ML, Figueiredo TM. The comorbidity tuberculosis and diabetes mellitus. Rev Enferm UFPE. 2016;10(1):239-47. https://doi.org/10.5205/reuol.7901-80479-1-SP.1001sup201607

15. Noubiap JJ, Nansseu JR, Nyaga UF, Nkeck JR, Endomba FT, Kaze AD, et al. Global prevalence of diabetes in active tuberculosis: a systematic review and meta-analysis of data from 2-3 million patients with tuberculosis. Lancet Glob Health. 2019;7(4):e448-e460. https://doi. org/10.1016/S2214-109X(18)30487-X

16. Ekeke KN, Ukwaja K, Chukwu JN, Nwafor CC, Meka AO, Egbagbe EE. Screening for diabetes mellitus among tuberculosis patients in Southern Nigeria: a multi-centre implementation study under programme settings. Sci Rep. 2017;7:44205. https://doi.org/10.1038/ srep44205

17. Tenaye L, Mengiste B, Baraki N, Mulu E. Diabetes Mellitus among adult tuberculosis patients attending tuberculosis clinics in Eastern Ethiopia. Biomed Res Int. 2019;2019:7640836. https://doi.org/10.1155/2019/7640836

18. Pande T, Huddart S, Xavier W, Kulavalli S, Chen T, Pai M, et al. Prevalence of diabetes mellitus amongst hospitalized tuberculosis patients at an Indian tertiary care center: a descriptive analysis. PloS one. 2018;13(7):e0200838. https://doi.org/10.1371/journal.pone.0200838

19. International Diabetes Federation (IDF). IDF Diabetes Atlas. Ninth edition 2019 [Internet]. Brussels, Belgium: IDF; 2019 [cited 2020 Nov 6]. Available from: https://www.diabetesatlas.org/upload/resources/material/20200302_133351_IDFATLAS9e-final-web.pdf

20. Ministério da Saúde (BR). Manual de Recomendações para o Controle da Tuberculose no Brasil [Internet]. Brasília, DF: Ministério da Saúde; 2019 [cited 2020 Nov 6]. Available from: https://bvsms.saude.gov.br/bvs/publicacoes/ manual_recomendacoes_controle_tuberculose_brasil_2_ed.pdf

21. Abreu RG, Rolim LS, Sousa Al, Oliveira MR, Sanchez MN. Tuberculose e diabetes: relacionamento probabilístico de bases de dados para o estudo da associação entre ambas doenças. Epidemiol Serv Saúde. 2017;26(2):359-68. https://doi.org/10.5123/s1679-49742017000200013

22. Sousa GG, Pascoal LM, Ferreira AG, Rolim IL, Santos LF, Santos Neto M. Clinical-epidemiological characterization of tuberculosis/diabetes comorbidity: integrative review. Rev Enferm UERJ. 2020;28:e50255. https://doi.org/10.12957/reuerj.2020.50255

23. Ministério da Saúde (BR). Brasil livre da tuberculose: plano nacional pelo fim da tuberculose como problema de saúde pública [Internet]. Brasília, DF: Ministério da Saúde; 2017 [cited 2020 Nov 6]. Available from: http://bvsms.saude.gov.br/bvs/publicacoes/brasil_livre_ tuberculose_plano_nacional.pdf

24. Abreu RG, Rolim LS, Sousa Al, Oliveira MR. Tuberculose e diabetes: associação com características sociodemográficas e de diagnóstico e tratamento. Brasil, 2007-2011. Rev Bras Epidemiol. 2020;23:e200009. https://doi.org/10.1590/1980-549720200009

25. Pereira SM, Araújo GS, Santos CA, Oliveira MG, Barreto ML. Associação entre diabetes e tuberculose: estudo caso controle. Rev Saude Publica. 2016;50:82. https://doi.org/10.1590/S1518-8787.2016050006374

26. Latorre MRDO, Cardoso MRA. Análise de séries temporais em epidemiologia: uma introdução sobre os aspectos metodológicos. Rev Bras Epidemiol. 2001;4(3):145-52. https://doi.org/10.1590/S1415-790X2001000300002

27. Instituto Brasileiro de Geografia e Estatística (IBGE). Brasil/Maranhão/Imperatriz [Internet]. Rio de Janeiro: IBGE; 2020 [cited 2020 Nov 6]. Availalble from: https://cidades.ibge.gov.br/brasil/ma/imperatriz/panorama

28. Leão HC, Valente Jr AS. Perfil econômico do Maranhão. Informe ETENE [Internet]. 2018 [cited 2020 Nov 6]. Availalble from: https://www.bnb. gov.br/documents/80223/1103955/Ano+3_n3_Set_2018.pdf/06d9f1df-e0be-e671-9852-0b9d436be9ea

29. Ministério da Saúde (BR). Panorama da tuberculose no Brasil: diagnóstico situacional a partir de indicadores epidemiológicos e operacionais [Internet]. Brasília, DF: Ministério da Saúde; 2018 [cited 2021 Jan 5]. Available from: http://bvsms.saude.gov.br/bvs/publicacoes/ tuberculose_brasil_indicadores_epidemiologicos_operacionais.pdf

30. Ministério da Saúde (BR). Datasus. Informações de Saúde - TABNET [Internet]. Brasília, DF: Ministério da Saúde; 2016 [cited 2021 Jan 6 ]. Available from: http://www2.datasus.gov.br/DATASUS/index.php?area=02

31. Wooldridge JM. Introductory econometrics: a modern approach. 4. ed. Mason: South Western; 2009.

32. Antunes JL. Mortalidade por câncer e desigualdade social em São Paulo [Tese]. São Paulo. Universidade de São Paulo; 2005.

33. Barros AJ, Hirakata VN. Alternatives for logistic regression in cross-sectional studies: an empirical comparison of models that directly estimate the prevalence ratio. BMC Med Res Methodol. 2003;3:21. https://doi.org/10.1186/1471-2288-3-21

34. Zou G. A modified poisson regression approach to prospective studies with binary data. Am J Epidemiol. 2004;159(7):702-6. https://doi. org/10.1093/aje/kwh090

35. Curreau FV, Teló GH, Souza MS, Côpes FS, Schaan BD. Prevalence of diabetes mellitus in Brazil: a systematic review with meta-analysis. Diabetol Metab Syndr. 2015;11:7. https://doi.org/10.1186/s13098-016-0181-1

36. Ko PY, Lin SD, Tu ST, Hsieh MC, Su SL, Hsu SR, et al. High diabetes mellitus prevalence with increasing trend among newly-diagnosed tuberculosis patients in an Asian population: a nationwide population-based study. Prim Care Diabetes. 2016;10(2):148-55. https://doi. org/10.1016/j.pcd.2015.09.005 
37. Armstrong LR, Kammerer JS, Haddad MB. Diabetes mellitus among adults with tuberculosis in the USA, 2010-2017. BMJ DRC. 2020;8:e001275. https://doi.org/10.1136/bmjdrc-2020-001275

38. Moreno-Martínez A, Casals M, Orcau A, Gorrindo P, Masdeu E, Cayla, JA. Factors associated with diabetes mellitus among adults with tuberculosis in a large European city, 2000-2013. Int J Tuberc Lung Dis. 2015;19(12):1507-12. https://doi.org/10.5588/ijtld.15.0102

39. Ayelign B, Negash M, Genetu M, Wondmagegn T, Shibabaw T. Immunological impacts of diabetes on the susceptibility of mycobacterium tuberculosis. J Immunol Res. 2019. https://doi.org/10.1155 / 2019/6196532

40. Evangelista MS, Maia R, Toledo JP, Abreu RG, Barreira D. Tuberculosis associated with diabetes mellitus by age group in Brazil: a retrospective cohort study, 2007-2014. Braz J Infect Dis. 2020;24(2):130-6. https://doi.org/10.1016/j.bjid.2020.03.005

41. Workneh MH, Bjune GA, Yimer SA. Prevalence and associated factors of tuberculosis and diabetes mellitus comorbidity: a systematic review. PloS One. 2017;12(4):1-25. https://doi.org/10.1371/journal.pone.0175925

42. Céspedes C, López L, Aguirre S, Mendoza-Ticona A. [Prevalence of comorbidity tuberculosis-diabetes mellitus in Paraguay], 2016 and 2017. Rev Panam Salud Publica. 2019;43:e105. https://doi.org/10.26633/RPSP.2019.105. Spanish.

43. Ugarte-Gil C, Bachti A, Katharina R, Anca LR, Raspati CK, Stephanus TM, et al. Diabetes mellitus among pulmonary tuberculosis patients from 4 tuberculosis-endemic countries: the TANDEM Study. Clin Infect Dis. 2020;70(5):780-8. https://doi.org/10.1093/cid/ciz284

44. Fontes GJ, Silva TG, Sousa JC, Feitosa AD, Silva ML, Bezerra AL, et al. Perfil epidemiológico da tuberculose no Brasil no período de 2012 a 2016. REBES. 2019;9(1):19-26. https://doi.org/10.18378/rebes.v9i1.6376

45. Flor LS, Campos MR. The prevalence of diabetes mellitus and its associated factors in the Brazilian adult population: evidence from a population-based survey. Rev Bras Epidemiol. 2017;20(1):16-29. https://doi.org/10.1590/1980-5497201700010002

46. Rodrigues WM, Mello AG. Tuberculosis and schooling: a literature review. RIAI. 2018;4(2). https://doi.org/10.17561/riai.v4.n2

47. Canto VB, Nedel FB. Completeness of tuberculosis records held on the Notifiable Health Conditions Information System (SINAN) in Santa Catarina, Brazil, 2007-2016. Epidemiol Serv Saúde. 2020;9(3):e2019606. https://doi.org/10.5123/s1679-49742020000300020

48. Allgaye MF, Ely KZ, Freitas GH, Valim AR, Gonzales RI, Krug SB, et al. Tuberculosis: health care and surveillance in prisons. Rev Bras Enferm. 2019;72(5):1304-10. https://doi.org/10.1590/0034-7167-2018-0260

49. Martellet MG, Siqueira TC, Tavernard GL, Orfão NH. Performance of nurses on tuberculosis in Primary Health Care: a literature review. J Infec Control. 2020;10(2). https://doi.org/10.17058/jeic.v10i2.13874 